\title{
Review: Penyakit virus corona baru 2019 (COVID-19)
}

\author{
Nany Hairunisa ${ }^{1}$, Husnun Amalia ${ }^{2}$
}

\begin{abstract}
ABSTRAK
Sebuah virus corona baru diidentifikasi sebagai SARS-CoV-2, pertama kali teridentifikasi di Wuhan, Cina, pada Desember 2019 dan dikenal dengan nama COVID-19. Memiliki 85\% homologi dengan SARS$\mathrm{CoV}, \mathrm{S}$-protein pada virus ini akan mengikat reseptor target (ACE2) pada manusia terutama pada paru, jantung, dan ginjal. COVID-19 memiliki masa inkubasi lebih lama dan penularannya lebih tinggi. Penularan terjadi melalui droplet saluran nafas dan kontak erat dengan penderita. Pandemi terjadi dengan sangat cepat, hingga 19 Mei 2020 telah teridentifikasi 4.943.077 kasus dengan angka kematian 321.998 orang dari 212 negara. Gejala yang paling sering muncul adalah demam, fatique, batuk kering, myalgia, dan sesak. Tingkat keparahan penyakit meningkat pada lansia dan penderita dengan comorbid (penyakit jantung, diabetes melitus, penyakit paru kronis, hipertensi, dan kanker). Infeksi ini memiliki CFR sebesar $2.3 \%$ dan komplikasi yang paling sering menyebabkan kematian adalah komplikasi pada jantung dan paru. Hingga saat ini belum ditemukan pengobatan yang tepat maupun vaksin untuk penyakit ini, namun penelitian guna pengembangan pengobatan dan vaksin terus dilakukan di seluruh dunia. Upaya maksimal harus dilakukan karena wabah ini mempengaruhi infrastruktur kesehatan publik, ekonomi, dan seluruh aspek di semua negara di dunia. Tindakan pencegahan adalah sangat penting sebagai upaya memutus mata rantai penularan COVID-19.
\end{abstract}

Kata kunci: COVID-19, SARS-CoV, virus corona

\author{
${ }^{1}$ Departemen Ilmu Kedokteran \\ Kerja, Fakultas Kedokteran \\ Universitas Trisakti, Indonesia \\ ${ }^{2}$ Departemen Ilmu Penyakit Mata, \\ Fakultas Kedokteran Universitas \\ Trisakti, Jakarta, Indonesia
}

\section{Korespondensi:}

Nany Hairunisa

Departemen Ilmu Kedokteran

Kerja, Fakultas Kedokteran

Universitas Trisakti,

Jalan Kyai Tapa, Kampus B,

Grogol, Jakarta Barat 11440,

Indonesia

Email: nanyhairunisa@trisakti.ac.id

J Biomedika Kesehat 2020;3(2):90-100 DOI: 10.18051/JBiomedKes.2020. v3.90-100

pISSN: 2621-539X / eISSN: 2621-5470

Artikel akses terbuka (open access) ini didistribusikan di bawah lisensi Creative Commons Attribution 4.0 International (CC-BY 4.0) 
ABSTRACT

\section{A review of Coronavirus Disease-2019 (COVID-19)}

A new coronavirus, identified as SARS-CoV-2, was first identified in Wuhan, China, in December 2019 and known as COVID-19. Having 85\% homology with SARS-CoV, S-protein in this virus will bind the target receptor (ACE2) in humans, especially in the lungs, heart, and kidneys. COVID-19 has a longer incubation period and higher transmission. Transmission occurs through respiratory droplets and close contact with sufferers. The pandemic occurred very quickly until 19 May 20204.943 .077 cases had been identified with a mortality rate of 321,998 people from 212 countries. The most common symptoms are fever, fatigue, dry cough, myalgia, and spasms. The disease severity is increasing in the elderly and patients with comorbidities (heart disease, diabetes mellitus, chronic lung disease, hypertension, and cancer). This infection has a CFR of $2.3 \%$, and the complications that most often cause death are heart and lung complications. Until now, there has not been found an appropriate treatment or vaccine for this disease. Research for the development of medicines and vaccines continues to be carried out throughout the world because this outbreak affects public health infrastructure, the economy, and all aspects of all countries of the world. Preventive action is critical as an effort to break the chain of transmission of COVID-19.

Keywords: COVID-19, SARS-CoV, coronavirus

\section{PENDAHULUAN}

Penyakit akibat virus corona atau Corona Virus Disease (COVID) adalah sebuah pandemi yang muncul pada awal tahun 2020. Virus ini menyebar dengan sangat cepat ke negara-negara di seluruh dunia. Desember 2019 rumah sakit di Wuhan, Cina melaporkan sejumlah kasus pneumonia idiopatik yang sumber infeksinya diduga berasal dari pasar grosir makanan laut. Fluktuasi pengunjung menyebabkan infeksi menyebar dengan cepat ke daerah lain di Cina. Pemeriksaan dengan RT-PCR (Real TimePolymerase Chain Reaction) mengidentifikasi virus baru yang diberi label Severe Acute Respiratory Syndrome Coronavirus 2 (SARS$\mathrm{CoV}-2)$ sebagai penyebabnya. Penyakit akibat virus ini dikenal dengan COVID-19..$^{(1,2)}$ Jenis coronavirus ini adalah patogen yang muncul kembali dan menjadi tantangan global bagi kesehatan masyarakat. ${ }^{(2)}$

\section{Struktur dan siklus hidup virus}

Coronavirus $(\mathrm{CoV})$ merupakan keluarga besar virus RNA (Ribo Nucleic Acid) yaitu virus ber-strand tunggal yang termasuk ordo Nidoviral, yang terdiri dari famili Coronaviridae, Roniviridae, Mesoniviridae dan Arteriviridae. ${ }^{(3,4)}$ Famili Coronaviridae dapat dibagi menjadi dua subfamili yaitu Coronavirinae dan Torovirinae. Subfamili Coronavirinae terbagi menjadi 4 genus yaitu alfa, beta, gamma dan delta. ${ }^{(3-5)}$ Dua genus yang dapat menginfeksi manusia adalah genus alfa dan beta. ${ }^{(5)}$

Virus ini memiliki struktur sebagai virus enveloped RNA dalam lipid bilayer. ${ }^{(1)}$ SARS-
CoV-2 adalah sebuah partikel berbentuk bulat atau oval, sering ditemukan juga berbentuk polimorfik dengan diameter 60-140 nm. ${ }^{(6)}$ Karakteristik genetiknya sangat berbeda dengan SARSr-CoV (Severe Acute Respiratory Syndrome Coronavirus) dan MERSr-CoV (Middle East Respiratory Syndrome Coronavirus), homologinya mencapai $85 \%$ dengan SARSr-CoV.

RNA virus ini memiliki panjang genom sekitar 26 hingga $32 \mathrm{kPa} .^{(7)}$ Lipid bilayer pada virus akan berfusi dengan membran sel host. Kemudian akan terjadi realease RNA virus ke dalam sitoplasma dan dilanjutkan dengan translasi dari protein virus. Replikasi genome RNA dan sintesis protein virus akan membentuk virus baru dan keluar dari sel..$^{(1,8)}$

Virus ini memiliki glikoprotein pada permukaan virus yaitu spike (S)-glikoprotein. (5) Virus masuk melalui ikatan dengan 2 protein ini, yaitu spike protein (S-protein) yang mengekspresikan seperti homotrimer pada envelope virus. ${ }^{(1)}$ Pada setiap S-protein memiliki 2 subunit yaitu S1 dan S2. Subunit S1 terdiri dari receptor-binding domain yang akan mengikat reseptor target dari sel host, sedangkan subunit S2 akan mengatur proses fusi pada membran sel. S-protein ini akan berikatan dengan reseptor ACE2 (Angiotensin Converting enzyme 2) pada manusia. (9) Reseptor ACE2 terdapat banyak di paru-paru, jantung, ginjal dan jaringan adiposa. Ikatan 2 protein ini dapat dijadikan target untuk pengobatan dan vaksinasi. SARS-CoV-2 memiliki mekanisme memasuki sel host yang sama dengan SARS, namun kecepatannya lebih lambat. Perbedaannya adalah pada COVID-19, virus terakumulasi lebih 
banyak pada jaringan sistemuk, sehingga memiliki masa inkubasi yang lebih lama dan penularannya lebih tinggi. ${ }^{(10)}$

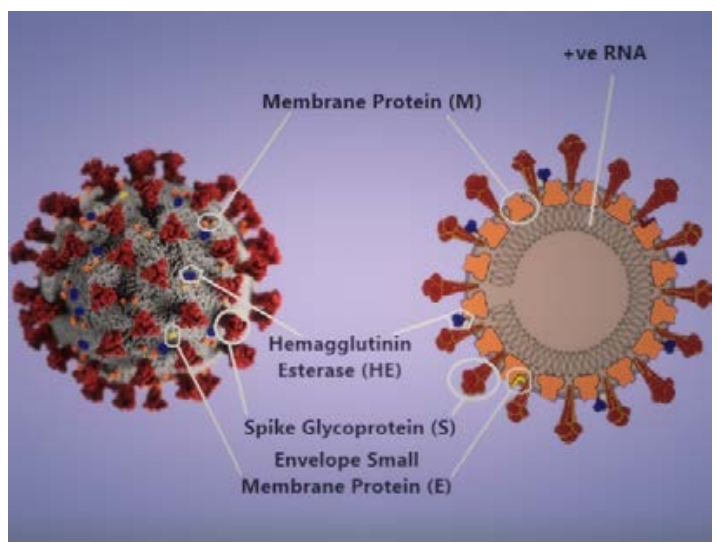

Gambar 1. Model 3-D struktur virus COVID-19(11)

\section{Transmisi}

Penyebaran virus ini terjadi dengan cepat. ${ }^{(5)}$ Sumber infeksi adalah penderita dengan pneumonia COVID-19. Transmisi atau penularan yang utama terjadi melalui droplet dari saluran nafas. ${ }^{(6)}$ Selain itu, transmisi terjadi akibat kontak erat dengan penderita. ${ }^{(1,6)}$ Pada beberapa kondisi dapat melalui transmisi udara (airborne). Pada penderita COVID-19 tidak ditemukan RNA di sampel urin maupun serum. ${ }^{(1)}$

Masa inkubasi dapat terjadi pada hari ke 0-5 (Gambar 2), dilaporkan rata-rata sekitar 3-9 hari dengan kisaran antara 0-24 hari. Pada Gambar 2 menunjukkan periode seseorang dapat menularkan (periode infeksi) terjadi lebih dulu sebelum muncul gejala, yaitu sekitar 2.5 hari lebih awal dari gejala. Diperkirakan $44 \%$ penularan terjadi pada periode tersebut. Melakukan kontak erat dengan seseorang yang berada dalam periode infeksi akan berisiko tertular. Namun, belum dapat diperkirakan faktor apa saja yang memastikan seseorang akan terinfeksi. ${ }^{(1)}$

Virus ditemukan teridentifikasi pada berbagai jenis hewan seperti kucing, burung, unta, anjing, kelelawar, tikus, dan hewan ternak. Proliferasi dan penyebaran Volatile organic compound (VOCs) membuat hewan menjadi host yang penting. Virus MERS-CoV terdeteksi pertama kali di Arab Saudi pada tahun 2012, sekitar 2.494 kasus terkonfirmasi dan menyebabkan 858 kematian. Pada tahun 2002, subspesies senyawa organik volatil beta dengan cepat meluas ke Guangdong, Cina. Epidemi menyebabkan 8.000 terinfeksi dan 774 tewas di 37 negara. ${ }^{(7)}$ Kemudian pada tahun 2020 muncul epidemi baru di Cina dan dinyatakan sebagai radang paru-paru yang penyebabnya tidak diketahui. Investigasi laboratorium dan sejumlah riset menyatakan telah mengakui bahwa penyebab radang ini adalah jenis rantai berbeda dari MERS-CoV, yaitu senyawa organik volatile. ${ }^{(4)}$ Pada awalnya virus itu diklasifikasikan sebagai 2019-nCoV yaitu SARSCoV-2 menurut International Classification of Virus $(I C V) .^{(12)}$ Hasil isolasi sampel dari saluran pernafasan bawah penderita di Wuhan menunjukkan virus ini berasal dari genus beta. ${ }^{(6)}$ Kemudian Organisasi Kesehatan Dunia (WHO) mengumumkan bahwa penyakit yang disebabkan oleh coronavirus-2019 ini adalah (COVID-19) pada tanggal 11 Februari 2020. ${ }^{(12)}$

\section{Penyebaran COVID-19}

Pada Desember 2019, rumah sakit setempat di kota Wuhan, Cina, mulai didatangi pasien dewasa dengan gejala sindrom pernapasan akut yang parah tanpa diketahui penyebabnya. Kasus-kasus awal umumnya adalah orang terpapar makanan laut dari toko Huanan. Tim surveillance mengambil sampel dari saluran pernapasan pasien

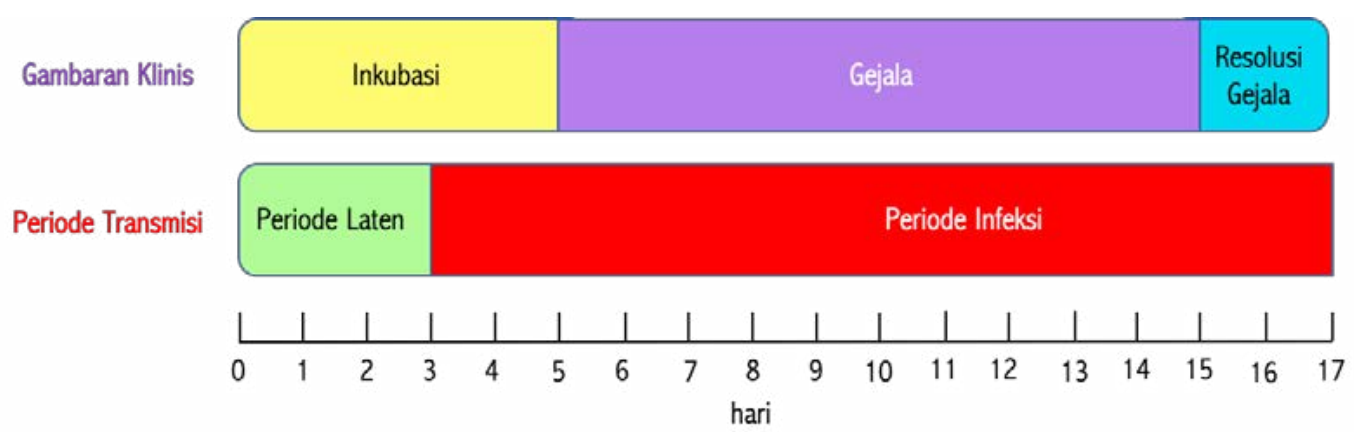

Gambar 2. Representasi klinis dan periode transmisi COVID-19 


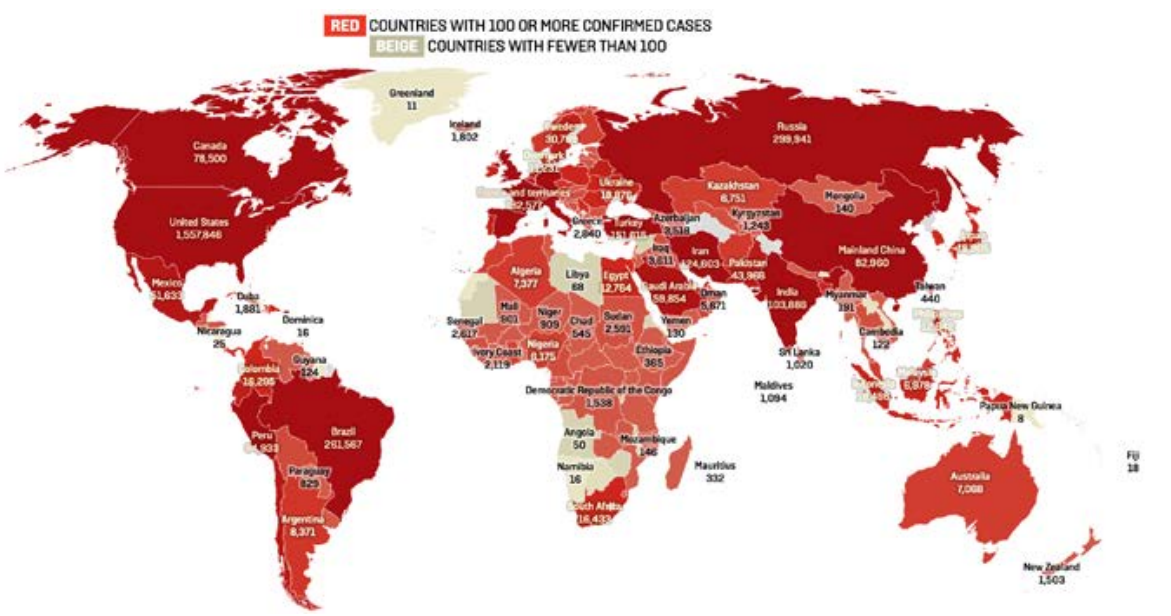

Gambar 3. Penyebaran COVID-19 di dunia(14)

Keterangan : warna merah adalah negara dengan kasus terkonfirmasi $\geq 100$; warna beige adalah negara dengan kasus terkonfirmasi $<100$

dan dikirim ke laboratorium rujukan untuk dicari penyebabnya. Kemudian pada 31 Desember 2019 , Cina melaporkan terjadinya wabah ini kepada WHO, dan pada 1 Januari 2020 diintruksikan toko makanan laut Huanan ditutup. Pada 7 Januari 2020, diketahui virus ini adalah coronavirus yang memiliki kemiripan mencapai 95\% dengan coronavirus dari kelelawar dan sekitar $70 \%$ dengan SARS-CoV. Sampel yang berasal dari lingkungan restoran makanan laut Huanan juga positif, menunjukkan secara signifikan bahwa virus ini berasal dari tempat tersebut. Selanjutnya jumlah kasus mulai meningkat, hal ini menunjukkan bahwa sumber penularan bukan dari hewan hidup di pasar namun sudah terjadi dari manusia ke manusia yang lain.Pada 11 Januari 2020 dilaporkan kasus fatal pertama. Migrasi besar-besaran pada perayaan Tahun Baru Cina memicu terjadinya pandemi. Penemuan kasus di luar provinsi dan negara lainnya (Thailand, Jepang, Korea Selatan) berasal dari orang-orang dengan riwayat kembali dari Wuhan. Pada tanggal 23 Januari diberlakukan status lockdown untuk 11 juta penduduk di Wuhan. Setelah itu, segera diberlakukan juga status yang sama ke kota-kota lain di provinsi Hubei. Jumlah Infeksi terus meningkat dengan cepat, laporan menunjukkan waktu pandemi jumlahnya akan dua kali lipat dalam 1,8 hari. ${ }^{(13)}$

Bulan Februari 2020 di Cina terjadi peningkatan kasus mencapai 15.000 dalam satu hari. Pada 3 Mei 2020 total kasus semakin meningkat dan mencapai 96.000 kasus di seluruh dunia (80.000 kasus di Cina), yang terdiri dari 87 negara dan 1 transportasi internasional (696 kasus berasal dari di kapal pesiar Diamond). Penting untuk diperhatikan bahwa saat jumlah kasus di Cina mengalami penurunan jumlah maka tampak jumlah kasus baru semakin meningkat di negaranegara lainnya seperti Iran, Korea Selatan, dan Italia. $^{(13)}$

Hingga 18 Juni 2020, COVID-19 telah menginfeksi 212 negara dengan 8.242.999 kasus, angka kematian mencapai 445.535 orang. ${ }^{(15)}$ Angka kematian (mortality rate) diperkirakan oleh WHO mencapai 3.4\%. Umumnya angka kematian akan terjadi lebih tinggi pada awal pandemi. ${ }^{(16)}$ Namun, pada tanggal 19 Juni 2020 menunjukkan angka kematian mencapai 5.4\%.

Kementerian Kesehatan Republik Indonesia pada 18 Juni 2020 mencatat terdapat 41.431 kasus terkonfirmasi, 2.339 kasus meninggal dengan CFR 5.5\%.(17) Pada 18 Juni 2020 dilaporkan tambahan kasus baru harian meningkat dari rata-rata $1.000-1.100$ kasus menjadi 1.331 kasus. Penambahan tertinggi terjadi di Jawa Timur (384 kasus) dan DKI Jakarta (173 kasus). ${ }^{(18)}$ Penambahan kasus tersebut adalah akumulasi dari hasil uji pemeriksaan spesimen sebesar 19.757 pada hari sebelumnya dari uji pemeriksaan menggunakan PCR (Polymerase Chain Reaction) di 121 laboratorium, TCM (Tes Cepat Molekular) di 87 laboratorium dan RT-PCR di 227 laboratorium. ${ }^{(19)}$ Sehingga merupakan hasil dari kontak tracing yang masif dan agresif, dan 


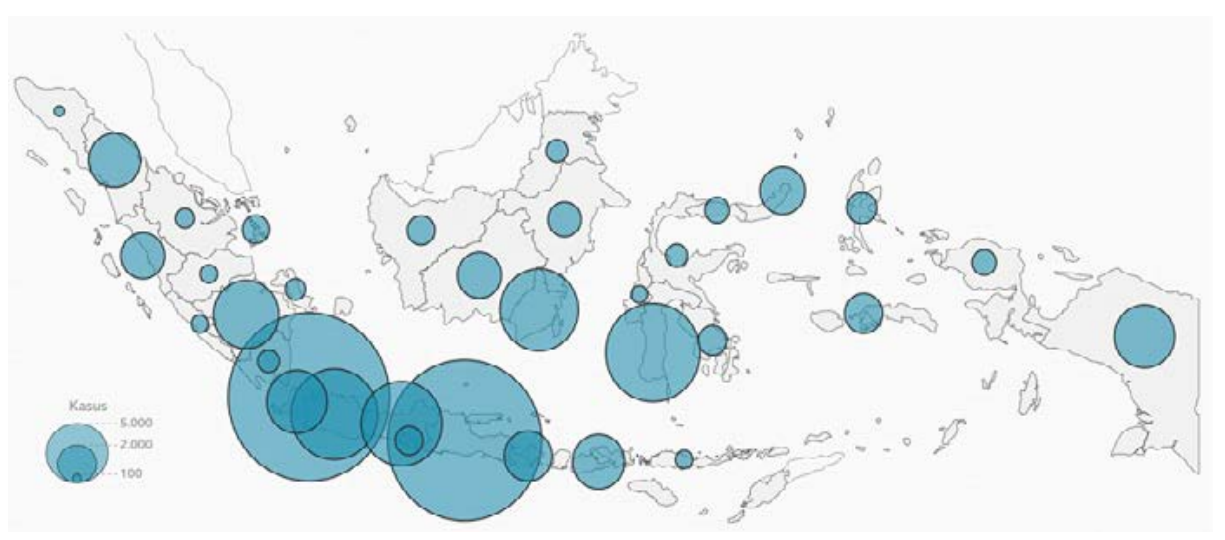

Gambar 4. Penyebaran COVID-19 di Indonesia ${ }^{(18)}$

gambaran ini menunjukkan kita harus mengetatkan kembali pengendalian sebaran penyakit dengan menjalankan protokol secara ketat. Saat ini 5 provinsi tertinggi dalam jumlah kasus COVID-19 adalah DKI Jakarta (9.349), Jawa Timur (8.533), Sulawesi Selatan (3.200), Jawa Barat (2.703) dan Jawa Tengah (2.346). ${ }^{(18)}$

\section{Gambaran klinis}

Penderita COVID-19 sebagian besar berumur berumur 30-79 tahun. ${ }^{(20)}$ Diagnosis COVID-19 selama ini dilakukan dengan menggunakan real-time reverse-transcriptase polymerase chain reaction (rRT-PCR). Namun, metode ini tidak tersedia secara luas, mengingat pelaksanaan prosedur rRT-PCR dalam mendiagnosa COVID-19 mungkin memerlukan pengamanan laboratorium dengan spesifikasi bio safety level III (BSL 3). Kemudian klinisi mulai mencoba mengevaluasi kondisi klinis untuk memandu diagnosis dan penggunaan alat rapid test yang berkualitas dan secara tepat dapat memberikan sensitivitas sebesar $88.6 \%$ dan spesifisitas mencapai $90 \%{ }^{(21)}$

Tanda dan gejala yang umum ditemukan adalah gangguan pernapasan akut seperti demam, batuk, dan sesak napas. Pada kasus yang berat dapat menyebabkan pneumonia, sindrom pernapasan akut, gagal ginjal, dan bahkan kematian. Tandatanda dan gejala klinis yang dilaporkan pada sebagian besar kasus adalah demam, dengan beberapa kasus mengalami kesulitan bernapas, dan hasil rontgen menunjukkan infiltrat pneumonia luas di kedua paru. ${ }^{(22)}$

Gejala yang paling sering dikeluhkan penderita adalah demam (98.6\%), fatigue (69.6\%), batuk kering (59.4\%), myalgia (34.8\%), dan sesak (31.2\%). Keluhan yang lebih jarang muncul adalah nyeri kepala, dizziness, nyeri perut, diare, mual, dan muntah. Pada penelitian tersebut menunjukkan terdapat perbedaan yang signifikan bahwa yang memerlukan ICU adalah penderita yang berusia lebih tua dan memiliki comorbid, dibandingkan yang tidak memerlukan ICU. ${ }^{(23)}$

Gejala yang dirasakan oleh penderita COVID-19 mirip dengan penderita SARS. Gejala serupa dengan flu, namun gejala yang timbul dapat berbeda-beda pada setiap individu. Kebanyakan orang yang terinfeksi akan mengalami gejala ringan hingga sedang. Center for Disease Control (CDC) menyatakan saat ini dilaporkan dapat terjadi gejala tambahan berupa kehilangan bau dan rasa. ${ }^{(13)}$

Infeksi ini memiliki case-fatality rate (CFR) sebesar 2.3\%. CFR akan meningkat bila penderita memiliki comorbid seperti penyakit jantung, diabetes melitus, penyakit paru kronis, hipertensi, dan kanker. ${ }^{(20)}$ Saat ini ada dugaan bila seseorang sedang dalam pengobatan dengan golongan obat angiotensin-converting enzyme inhibitors (ACEIs) dan Angiotensin-Receptor Blocker (ARB) akan meningkatkan risiko infeksi dan keparahan COVID-19. Penelitian pada hewan menunjukkan bahwa bila pemberian intravena kedua obat tersebut akan meningkatkan jumlah reseptor ACE2 di sirkulasi jantung paru. Reseptor ACE2 adalah reseptor yang mengikat virus SARSCoV-2 di paru-paru. ${ }^{(24)}$

Penelitian diCina menyatakan penegakkan diagnosis kasus di negaranya berdasarkan beberapa cara, yaitu $62 \%$ kasus berdasarkan hasil pemeriksaan swab tenggorok, $22 \%$ berdasarkan gejala dan riwayat kontak dan tanpa dilakukan tes, $15 \%$ berdasarkan pemeriksaan (gejala, riwayat 
kontak, dan gambaran radiologis paru) dan $1 \%$ berdasarkan tes namun tanpa gejala. ${ }^{(20)}$

\section{Definisi kasus dan komplikasi}

Berdasarkan beratnya kasus, COVID-19 dibedakan atas beberapa kelompok yaitu: 1) tanpa gejala; 2) ringan atau tidak berkomplikasi; 3) sedang atau moderat; 4) berat atau pneumonia berat; dan 5) kritis. Kelompok tanpa gejala bila pada penderita tidak ditemukan gejala. Kelompok ringan atau tidak berkomplikasi adalah penderita dengan infeksi saluran nafas tanpa komplikasi dan gejala tidak spesifik (demam, lemah, batuk, anoreksia, sesak ringan, kongesti hidung, sakit kepala, diare, mual, dan muntah). Kelompok sedang atau moderat adalah penderita remaja atau dewasa dengan pneumonia tapi tidak berat dan tidak memerlukan suplementasi oksigen, atau penderita anak dengan pneumonia berat, batuk, sulit bernafas, dan nafas cepat. ${ }^{(25)}$

Kelompok berat atau pneumonia berat adalah penderita remaja atau dewasa dengan demam demam atau pengawasan infesksi saluran nafas atau pneumonia ditambah salah satu gejala; frekuensi nafas napas $\geq 30 \mathrm{x} /$ menit, distress pernapasan berat, atau saturasi oksigen $(\mathrm{SpO} 2)$ $<93 \%$ pada udara kamar atau rasio $\mathrm{PaO} 2 / \mathrm{FiO} 2<$ 300. Atau pasien anak dengan batuk atau kesulitan bernapas, ditambah setidaknya salah satu; sianosis sentral atau $\mathrm{SpO} 2<90 \%$, distres pernapasan berat (seperti mendengkur, tarikan dinding dada yang berat), tanda pneumonia berat (ketidakmampuan menyusui atau minum, letargi atau penurunan kesadaran, atau kejang), tanda lain dari pneumonia (tarikan dinding dada,takipnea $:<2$ bulan, $\geq 60 \mathrm{x} /$ menit; $2-11$ bulan, $\geq 50 \mathrm{x} /$ menit; $1-5$ tahun, $\geq 40 \mathrm{x} /$ menit; $>5$ tahun, $\geq 30 \mathrm{x} /$ menit). Kelompok kritis adalah penderita dengan gagal napas, Acute Respiratory Distress Syndrome (ARDS), syok sepsis, dan atau multiple organ failure. ${ }^{(25)}$

Komplikasi yang paling sering ditemukan adalah pada jantung dan paru, sehingga dapat menyebabkankematian pada penderita COVID-19. (26) Penderita COVID-19 yang mengalami ARDS mencapai $41.8 \%$. Hal ini disebabkan sel alveolar memiliki banyak reseptor ACE2, sehingga virus ini akan menyerang alveoli. ${ }^{(27)}$

Selain ARDS dapat terjadi myocardial injury yang mekanisme terjadinya melalui dua mekanisme. Pertama, sebagai akibat jantung memiliki reseptor ACE2 seperti yang terdapat di paru-paru, sehingga virus menyerang sel jantung. (27) Mekanisme kedua yaitu melalui badai sitokin yang terjadi pada infeksi COVID-19 dapat secara langsung menyebabkan myocardial injury. ${ }^{(28)}$

Pada kasus infeksi COVID-19 yang berat dapat timbul acute kidney injury. ${ }^{(29-31)}$ Teori yang sama dengan komplikasi sebelumnya yaitu dapat diakibatkan karena ginjal memiliki reseptor ACE2 atau dapat karena badai sitokin. ${ }^{(32)}$

Pada penderita COVID-19 dapat terjadi co-infection yaitu infeksi oleh mikroba patogen lainnya. Bakteri lebih sering ditemukan sebagai co-infection dibandingkan virus. Berdasarkan literatur, mikroba yang dapat menyebabkan coinfection adalah adalah respiratory syncytial virus (RSV), Influenza A, dan Influenza B. ${ }^{(33-35)}$

\section{Tata laksana}

Sebagai langkah awal adalah isolasi yang adekuat untuk mencegah transmisi melalui kontak, penderita, dan tenaga kesehatan. Pada infeksi yang masih ringan terapi cukup dilakukan isolasi mandiri di rumah dengan tetap melakukan monitor pada asupan cairan dan nutrisi. Dilakukan juga pengontrolan terhadap demam dan batuknya. ${ }^{(13)}$ Sesuai dengan protokol tata laksana COVID-19 di Indonesia pada penderita terkonfirmasi namun tanpa gejala maka dilakukan isolasi mandiri 14 hari di rumah dan pemantauan oleh petugas. Selain itu, diberikan tata laksanan non farmakologis berupa edukasi (pengukuran suhu $2 \mathrm{x}$ sehari, gunakan masker bila bepergian, cuci tangan dengan air mengalir menggunakan sabun atau gunakan cairan pembersih tangan sesering mungkin, physical distancing, tidur terpisah dengan anggota keluarga lain, etika batuk yang benar (menutup mulut saat batuk), alat makan dan minum sendiri, berjemur matahari minimal 10-15 menit/hari, pakaian dicuci terpisah, ventilasi ruangan harus baik dan bersihkan kamar dengan desinfektan secara berkala). Bila penderita memiliki penyakit comorbid dianjurkan melanjutkan pengobatan rutinnya dan vitamin C selama 14 hari. ${ }^{(25)}$

Hal yang berbeda dinyatakan penelitian lainnya yaitu semua yang suspek dan penderita yang terkonfirmasi harus dilakukan tata laksana di rumah sakit dengan isolasi yang efektif. Penderita suspek masing-masing harus dirawat pada ruangan terpisah, sedangkan penderita yang 
sudah terkonfirmasi dapat dirawat gabung dengan penderita lainnya, dan penderita yang kritis harus segera dirawat di ICU. ${ }^{(6)}$

Kelompok ringan dilakukan tata laksana yang sama dengan penderita tanpa gejala dengan tambahan pengobatan Kloroquin fosfat $500 \mathrm{mg} / 12$ jam oral (5 hari, Azitromisin $500 \mathrm{mg}$ dosis tunggal oral atau levofloksasi $750 \mathrm{mg}$ dosis tunggal oral (5 hari), bila diperlukan tambahan antivirus Oseltamivir $75 \mathrm{mg} / 12$ jam oral atau Favipiravir $600 \mathrm{mg} / 12$ jam oral (5 hari). ${ }^{(25)}$

Kelompok sedang atau moderat segera dirujuk ke rumah sakit untuk diisolasi dan dirawat selama 14 hari agar dapat beristirahat total, intake adekuat dan pemantauan oleh tenaga medis. Perlu dilakukan pemeriksaan laboratorium darah perifer lengkap dengan hitung jenis, CRP (C-Reactive Protein), fungsi ginjal, fungsi hati, dan foto rontgen thorak. Pengobatan farmakologis diberikan jenis yang sama dengan kelompok gejala ringan namun dosis dan cara pemberian yang berbeda. Vitamin C 200-400 mg/8jam dalam $100 \mathrm{cc} \mathrm{NaCl} \mathrm{0.9 \%} \mathrm{secara}$ drip iv (habis dalam 1 jam), kloroquin dosis sama per oral selama 5-7 hari. Azitromisin dosis sama dapat per oral atau iv selama 5-7 hari demikin juga bila diberikan levofloksasin. Dosis Oseltamivir sama namun bila diberikan Favipiravir secara loading dose $1600 \mathrm{mg} / 12 \mathrm{jam} /$ oral hari ke-1 dan selanjutnya $2 \times 600 \mathrm{mg}$ (hari 2-5). ${ }^{(25)}$

Kelompok berat atau pneumonia berat dan kritis dilakukan tata laksana di rumah sakit sesuai dengan kelompok sedang. Namun, pemeriksaan laboratorium darah ditambahkan hemostasis, LDH (Lactate dehydrogenase) dan D-Dimer (pemeriksaan fibrin degradation fragment). Monitoring pernafasan, saturasi oksigen, limfopenia, kadar CRP, asidosis, dan keadaan kritis lainnya. Diberikan tata laksana adekuat sesuai kondisi. ${ }^{(25)}$

Saat ini belum ada terapi farmakologis yang khusus untuk virus ini dan belum ditemukan vaksin untuk penyakit ini. Tata laksana yang diberikan saat ini harus sesuai protokol dan terapi oksigen yaitu, intervensi utama pada penderita dengan infeksi berat. Ventilasi mekanik diberikan pada kasus kegagalan pernafasan yang tidak bereaksi terhadap terapi oksigen, sedangkan dukungan hemodinamik sangatlah penting untuk menjaga syok akibat septik. Prosedur persiapan dan tindakan intubasi pada ventilasi mekanik harus dilakukan oleh tenaga ahli dengan menggunakan Alat Pelindung Diri yaitu masker N95, kacamata pelindung, baju hazmat disposable, kaus kaki 2 lapis disposable, dan sarung tangan. ${ }^{(12)}$

Protokol tata laksana COVID-19 dengan comorbid telah disusun sesuai kelompoknya yaitu diabetes melitus (DM), geriatri, autoimun, penyakit ginjal, STEMI (ST-segmen elevation myocardial infarction), NSTEMI (ST-segmen elevation myocardial infarction), hipertensi, penyakit paru obstriksi kronik (PPOK), dan tuberkulosis (TB). Penderita diabetes melitus (DM) diberikan pengelolaan sesuai kadar glukosa dan tipe DM. Pada DM tipe 1 diberikan insulin, DM tipe 2 dapat diberikan insulin atau non insulin, dan pada Glucocorticoid-associated diabetes pemantauan kadar glukosa darah dan terapi insulin. ${ }^{(25)}$

Kelompok geriatri sangat rentan sehingga dilakukan pencegahan yaitu social dan physical distancing, penggunaan masker dan upaya lainnya. Dalam pelaksanaannya, perlu diperhatikan pula kesejahteraan dan kesehatan mental dari pasien geriatri tersebut. Pada kelompok autoimun belum dibuktikan ada peningkatakn risiko infeksi COVID-19 pada kelompok ini, anjurannya adalah tidak menghentikan pengobatan agar tidak memicu kondisi autoimunnya. Kelompok Penyakit ginjal rentan terhadap infeksi ini terutama pada penderita penyakit ginjal kronis (PGK), sehingga harus dilakukan pencegahan dengan tetap tinggal di rumah, mengurangi kontak, menggunakan masker dan tetap melanjutkan obat rutinnya. Semua pasien diminta untuk tetap melanjutkan terapi. ${ }^{(25)}$

Kelompok penderita STEMI dan NSTEMI memiliki prosedur kriteria skrining cepat COVID-19 untuk diagnosisnya, karena segera memerlukan tindakan medis, isolasi dan ruang intensive care (sesuai kondisi) bila terdeteksi terinfeksi COVID-19. Kelompok comorbid hipertensi merupakan salah satu yang paling sering ditemui pada penderita COVID-19. Pada penderita hipertensi masih diteliti apakah penggunaan ACEIs dan ARB, 2 golongan obat yang sering digunakan dalam mengontrol hipertensi, dipertanyakan akan memberikan maanfaat atau merugikan, karena ACE inhibitor dan ARB meningkatkan ACE2 sehingga secara teoritis akan meningkatkan ikatan SARS-Cov-2 ke paru-paru. Akan tetapi, ACE2 menunjukkan efek proteksi dari kerusakan paru pada studi 
eksperimental. ${ }^{(25)}$

Kelompok comorbid PPOK berisiko terhadap COVID-19 terutama PPOK berat sehingga disarankan meminimalisir konsultasi tatap muka dan bila diperlukan konsultasi secara tatap muka maka dilakukan skrining terlebih dahulu melalui telepon untuk memastikan pasien tidak ada gejala COVID-19 dan dilakukan tindakan pencegahan seperti kelompok lainnya. Penderita juga tetap secara rutin menggunakan obat-obatannya. Pada kelompok comorbid TB tetap diberikan pengobatan anti-TB sesuai standar dan dianjurkan tidak sering mengunjungi fayankes TB untuk mengambil obat. ${ }^{(25)}$

Pemberian sistemik kostikosteroid tidak direkomendasikan pada ARDS atau pneumonia akut. Terdapat penelitian yang melakukan pemberian remdesivir pada penderita COVID-19 yang dirawat di rumah sakit dan hasilnya adalah $68 \%$ pasien menunjukkan perbaikan secara klinis. ${ }^{(36)}$ Penelitian lainnya di Inggris pada bulan Maret sampai Juni 2010 menyatakan pemberian deksametason $6 \mathrm{mg} /$ hari selama 10 hari pada 2104 pasien dapat mengurangi kematian sepertiga pada pasien berventilasi $(\mathrm{p}=0.0003)$ dan seperlima pada pasien yang membutuhkan olsigen $(\mathrm{p}=0.0021)$. $^{(37)}$ Penelitian lainnya juga menyatakan bahwa 1542 pasien yang mendapatkan hydroxychloroquin tidak menunjukkan perbedaan yang signifikan dalam mortalitas $(p=0.10)$ ataupun efek lama perawatan di rumah sakit. ${ }^{(38)}$

Penelitian lainnya juga menunjukkan efektifitas antivirus di mana terdapat dua kelompok sampel (kelompok kombinasi dan kelompok kontrol). Kelompok kombinasi terdiri dari 86 penderita yang mendapatkan 14 hari terapi lopinavir-ritonavir (lopinavir $400 \mathrm{mg}$ dan ritonavir $100 \mathrm{mg}$ ) setiap $12 \mathrm{jam}$, ribavirin $400 \mathrm{mg}$ setiap 12 jam dan injeksi subkutaneus interferon beta- $1 \mathrm{~b} \quad 1 \mathrm{ml}$ (8 juta IU) secara alternate. Kelompok kontrol terdiri dari 41 pasien dan mendapatkan 14 hari terapi lopinavirritonavir setiap 12 jam dengan dosis yang sama dengan kelompok kombinasi. Hasil penelitian menyatakan kelompok kombinasi memiliki waktu median yang lebih cepat untuk mendapatkan hasil swab nasofaring negatif yaitu 7 hari, sedangkan pada kelompok kontrol adalah 12 hari $(\mathrm{p}=0.001)$. Kelompok kombinasi menunjukkan perbaikan secara klinis yang signifikan. Median lama waktu perawatan di rumah sakit menunjukkan perbedaan yang signifikan yaitu kelompok kombinasi 9 hari dan kelompok kontrol 14.5 hari $(p=0.016){ }^{(38)}$

Penelitian lainnya memberikan terapi plasma darah yang diperoleh dari pasien COVID-19 yang telah pulih pada 5 pasien kritis yang telah menggunakan ventilasi mekanik. Setelah dilakukan transfusi, suhu tubuh menjadi normal pada $80 \%$ pasien, skor SOFA (Sequential Organ Failure Assessment) menurun $\mathrm{PAO}_{2} / \mathrm{FIO}_{2}$ meningkat dalam 12 hari, viral load menurun dan menjadi negatif dalam 12 hari dan terjadi peningkatan status klinis. Hal ini menunjukkan pemberian plasma cukup efektif. ${ }^{(39)}$

\section{Prognosis dan pencegahan}

Secara umum seluruh populasi rentan terhadap infeksi virus ini. Terutama lanjut usia dan yang memiliki comorbid akan mengalami kondisi yang serius bila terinfeksi. Hampir seluruh penderita memiliki prognosis yang baik, gejala pada anak-anak umumnya relatif ringan hanya sebagian kecil yang kritis. Kematian lebih sering ditemukan pada lanjut usia dan penderita dengan penyakit kronis yang mendasari (comorbid) ${ }^{(6)}$

Tindakan pencegahan untuk penyakit ini sangat penting karena sampai saat ini belum ada pengobatan yang tepat. Penyakit ini sangat non spesifik seperti gejala yang sangat bervariasi, masa inkubasi yang panjang, periode infeksi yang mulai sebelum timbulnya gejala, penularan yang berasal dari penderita yang asimptomatik, durasi sakit yang panjang dan transmisi masih dapat terjadi walaupun penderita secara klinis telah pulih. ${ }^{(13)}$

Cara yang paling penting untuk mencegah tertularnya penyakit ini adalah sering cuci tangan dengan menggunakan sabun, gunakan cairan pembersih tangan, hindari tangan menyentuh mata, wajah, dan mulut, terapkan etika batuk atau bersin dengan menutup hidung dan mulut dengan lengan atas bagian dalam atau tisu, lalu buanglah ke tempat sampah. Pakailah masker medis bila memiliki gejalan gangguan pernafasan dan menjaga jarak minimal $1 \mathrm{~m}$ dengan orang yang mengalami gangguan pernafasan. ${ }^{(12,22)}$ Selain itu, hindari kontak erat dengan penderita infeksi saluran nafas akut (ISPA). Hindari kontak dengan hewan ternak dan hewan liar, dan bagi orang yang immunocompromised harus menghindari pertemuan/kerumunan publik..$^{(12)}$ 
Bila di rumah tinggal terdapat penderita terkonfirmasi, dan harus dirawat isolasi mandiri, maka ruangan harus memiliki ventilasi dan ckup masuk cahaya matahari ke ruangan tersebut. Bagi yang merawat harus menggunakan masker bila memasuki ruangan penderita dan cuci tangan dengan sabun atau menggunakan pembersih tangan setiap 15-20 menit. ${ }^{(13)}$

Masyarakat harus menjaga jarak sosial (social distancing) dan jarak fisik (physical distancing), menghindari tempat keramain (berkerumun) dan menunda perjalanan antar daerah yang tidak penting. Pada 15 April dilaporkan 23 negara telah memberlakukan lockdown melakukan untuk memutus rantai transmisi COVID-19. ${ }^{(40)}$

Pandemi di Indonesia telah berjalan selama lebih dari 3 bulan. Selama itu pula telah dilakukan langkah-langkah taktis dan aksi gerak cepat oleh pemerintah pusat maupun daerah dalam mencegah penyebaran virus SARS-CoV2. Kebijakan yang telah dilakukan yaitu, PSBB (Pembatasan Sosial Berskala Besar) dengan menghentikan kegiatan masal, meliburkan sekolah, memberlakukan work from home dan study from home, dan lain-lain. ${ }^{(41)}$

\section{KESIMPULAN}

Pandemi COVID-19 terjadi dengan sangat cepat. Virus SARS-CoV2 adalah patogen yang muncul dan menjadi tantangan global bagi kesehatan masyarakat. Transmisi terjadi melalui droplet dari saluran nafas. S-protein pada virus akan berikatan dengan reseptor ACE2 pada manusia yang banyak terdapat di paru-paru, jantung, ginjal, dan jaringan adiposa. Masa inkubasi rata-rata 3-9 hari dengan gejala yang muncul seperti, gangguan pernafasan akut dengan 98.6\% penderita mengalami demam. COVID-19 memiliki angka tingkat kematian kasus (Case Fatality Rate) $2.3 \%$ dan akan meningkat bila penderita memiliki comorbid yang menyebabkan komplikasi dan berakibat pada kematian. Saat ini belum ada terapi farmakologis yang khusus untuk virus ini dan belum ditemukan vaksin untuk penyakit ini. Namun, penelitian dalam bidang pengobatan dan pengembangan vaksin masih terus dilakukan di seluruh dunia, sehingga tindakan pencegahan menjadi sangat penting dilakukan pada penyakit ini. Cara yang paling penting untuk mencegah tertularnya penyakit ini adalah sering mencuci tangan dengan menggunakan sabun, gunakan cairan pembersih tangan, hindari tangan menyentuh mata, wajah, dan mulut, terapkan etika batuk atau bersin, gunakan masker, jaga jarak fisik dan sosial. Pemerintah telah melakukan langkah taktis dan aksi gerak cepat melalui kebijakankebijakannya untuk mencegah penyebaran virus SARS-CoV2.

\section{REFERENSI}

1. Siordia JA. Epidemiology and clinical features of COVID-19: A review of current literature. J Clin Virol. 2020;127:1-7. doi: 10.1016/j. jev.2020.104357

2. Zhu N, Zhang D, Wang W, et al. A novel coronavirus from patients with pneumonia in China, 2019. N Engl J Med. 2020;382(8):727-33. doi: 10.1056/ NEJMoa2001017

3. Fehr AR, Perlman S. Coronaviruses: Methods and protocols. In: Majer HJ, editor. Coronaviruses: Methods and Protocols, Methods in Molecular Biology. 1st ed. New York: Springer Science \& Business Media; 2015. p. 1-282.

4. Chen Y, Liu Q, Guo D. Emerging coronaviruses: Genome structure, replication, and pathogenesis. J Med Virol. 2020;92(4):418-23. doi: 10.1002/ jmv.25681

5. Paules CI, Marston HD, Fauci AS. Coronavirus Infections-More Than Just the Common Cold Catharine. JAMA. 2020;323(8):707-8. doi: 10.1001/jama.2020.0757

6. Jin YH, Cai L, Cheng ZS, et al. A rapid advice guideline for the diagnosis and treatment of 2019 novel coronavirus (2019-nCoV) infected pneumonia (standard version). Med J Chinese People's Lib Army. 2020;47(4):1-23. doi: 10.1186/ s40779-020-0233-6

7. Lu R, Zhao X, Li J, et al. Genomic characterisation and epidemiology of 2019 novel coronavirus: implications for virus origins and receptor binding. Lancet. 2020;395:565-74. doi: 10.1016/S01406736(20)30251-8

8. Qin P, Du EZ, Luo WT, et al. Characteristics of the life cycle of porcine deltacoronavirus (PDCoV) in vitro: Replication kinetics, cellular ultrastructure and virion morphology, and evidence of inducing autophagy. Viruses. 2019;11(5):1-14. doi: $10.3390 / \mathrm{v} 11050455$

9. Zhou P, Yang XL, Wang XG, et al. A pneumonia outbreak associated with a new coronavirus of probable bat origin. Nature. 2020;579(7798):270 3. doi: 10.1038/s41586-020-2012-7

10. Su Z, Wu Y. A Multiscale and Comparative Model for Receptor Binding of 2019 Novel Coronavirus and the Implication of its Life Cycle in Host Cells. Preprint. bioRxiv. 2020;2020.02.20.958272. doi:10.1101/2020.02.20.958272

11. Kakodkar P, Kaka N, Baig MN. A Comprehensive Literature Review on the Clinical Presentation, and Management of the Pandemic Coronavirus Disease 2019 (COVID-19). Cureus. 2020;12(4):e7560. doi: $10.7759 /$ cureus. 7560

12. Cascella M, Rajnik M, Cuomo A, et al. Features, Evaluation and Treatment Coronavirus (COVID-19). In: StatPearls. Treasure Island (FL): StatPearls Publishing; August 10, 2020. 1-17 p.

13. Singhal T. A Review of Coronavirus Disease-2019 
(COVID-19). Indian J Pediatr. 2020;87(4):281286. doi:10.1007/s12098-020-03263-6

14. Foreign Policy Staff. Coronavirus Map: Daily Updates on the Toll of the Outbreak [Internet]. Foreign Policy. 2020 Marc 1 [updated 2020 May 19; cited 2020 June 18] . Available from: https://foreignpolicy.com/2020/03/04/mappingcoronavirus-outbreak-infographic/

15. World Health Organization. WHO Coronavirus Disease (COVID-19) Dashboard [Internet]. 2020 [cited 18 June 2020]. Available from: https:// covid19.who.int/

16. Worldometer. Coronavirus update(Live): 1,925,224 cases and 119,702 deaths from COVID-19 virus pandemic [Internet]. Worldometers. 2020. Available from: https://www.worldometers.info/ coronavirus/

17. Kemenkes RI. Situasi Terkini Perkembangan Coronavirus Disease (COVID-19) 19 Juni 2020 [Internet]. Jakarta: Kemenkes RI; 2020 [cited 2020 June 19]. Available from: https://covid19.kemkes. go.id/situasi-infeksi-emerging/info-corona-virus/ situasi-terkini-perkembangan-coronavirusdisease-covid-19-19-juni-2020/\#.X1tJMmgzY2w

18. BBC Indonesia. Covid-19: Kasus baru Indonesia catat rekor 3.861, 33\% dari Jakarta [Internet]. Jakarta: BBC Indonesia; 2020 March 13 [cited 2020 June 18]. Available from: https://www.bbc. com/indonesia/indonesia-51850113

19. Tim Komunikasi Publik Gugus Tugas Nasional. Kasus Positif COVID-19 Naik 1.031, Pasien Sembuh Meningkat Jadi 16.243 [Internet]. Jakarta: Gugus Tugas Percepatan Penanganan COVID-19; 2020 June 17 [cited 2020 June 18]. Available from: https://covid19.go.id/p/berita/kasus-positifcovid-19-naik-1031-pasien-sembuh-meningkatjadi-16243

20. $\mathrm{Wu} \mathrm{Z}$, McGoogan JM. Characteristics of and Important Lessons From the Coronavirus Disease 2019 (COVID-19) Outbreak in China: Summary of a Report of 72314 Cases From the Chinese Center for Disease Control and Prevention. JAMA. 2020;323(13):1239-1242. doi:10.1001/ jama.2020.2648

21. Arif SK, Muchtar F, Wulung NL, et al. Buku Pedoman Penanganan Pasien Kritis COVID-19. 1st ed. Arif SK, Muchtar F, editors. Jakarta: PERDATIN; 2020.

22. Kemenkes RI. Pedoman Pencegahan dan pengendalian Coronavirus Disease (COVID-19). Jakarta: Kementrian Kesehatan RI; 2020. p. 115

23. Wang D, Hu B, Hu C, et al. Clinical Characteristics of 138 Hospitalized Patients With 2019 Novel Coronavirus-Infected Pneumonia in Wuhan, China. JAMA. 2020;323(11):1061-1069. doi:10.1001/ jama.2020.1585

24. Diaz JH. Hypothesis: angiotensin-converting enzyme inhibitors and angiotensin receptor blockers may increase the risk of severe COVID-19. J Travel Med. 2020;27(3):taaa041. doi:10.1093/jtm/taaa041

25. Burhan E, Susanto AD, Nasution SA, et al. Protokol Tatalaksana COVID-19. 1st ed. Jakarta: PDPI, PERKI, PAPDI, PERDATIN, IDAI; 2020

26. Ruan Q, Yang K, Wang W, et al. Clinical predictors of mortality due to COVID-19 based on an analysis of data of 150 patients from Wuhan, China. Intensive Care Med. 2020;46(5):846-848. doi:10.1007/s00134-020-05991-x

27. Turner AJ, Hiscox JA, Hooper NM. ACE2: From vasopeptidase to SARS virus receptor. Trends Pharmacol Sci. 2004;25(6):291-294. doi:10.1016/j. tips.2004.04.001

28. Zheng YY, Ma YT, Zhang JY, et al. COVID-19 and the cardiovascular system. N Nat Rev Cardiol. 2020;17(5):259-260. doi:10.1038/s41569-020$0360-5$

29. Wu C, Chen X, Cai Y, et al. Risk Factors Associated with Acute Respiratory Distress Syndrome and Death in Patients with Coronavirus Disease 2019 Pneumonia in Wuhan, China. JAMA Intern Med. 2020;180(7):934-943. doi:10.1001/ jamainternmed.2020.0994

30. Liu Y, Sun W, Li J, et al. Clinical features and progression of acute respiratory distress syndrome in coronavirus disease 2019. medRxiv. 2020.02.17.20024166; doi: 10.1101/2020.02.17.20024166

31. Pan XW, Xu D, Zhang H, et al. Identification of a potential mechanism of acute kidney injury during the COVID-19 outbreak: a study based on singlecell transcriptome analysis. Intensive Care Med. 2020 Jun;46(6):1114-1116. doi: 10.1007/s00134020-06026-1

32. Woelfel R, Corman VM, Guggemos W, et al. Virological assessment of hospitalized cases of coronavirus disease 2019. Nature 581, 465-469 (2020). doi:10.1038/s41586-020-2196-x

33. Ai J, Chen J, Wang Y, et al. The cross-sectional study of hospitalized coronavirus disease 2019 patients in Xiangyang, Hubei province. medRxiv. 2020;2020.02.19.20025023. doi: 10.1101/2020.02.19.20025023

34. Chen X, Zheng F, Qing Y, et al. Epidemiological and clinical features of 291 cases with coronavirus disease 2019 in areas adjacent to Hubei, China: a double-center observational study. medRxiv. 2020;2020.03.03.20030353. doi: 10.1101/2020.03.03.20030353

35. Xing Q, Li G, Xing Y, et al. Precautions Are Needed for COVID-19 Patients with Coinfection of Common Respiratory Pathogens [Internet]. SSRN. 2020. Available from: https://ssrn.com/ abstract $=3550013$

36. Grein J, Ohmagari N, Shin D, et al. Compassionate Use of Remdesivir for Patients with Severe Covid-19. N Engl J Med. 2020;382(24):23272336. doi:10.1056/NEJMoa2007016

37. Horby P, Landray M. Low-cost dexamethasone reduces death by up to one third in hospitalised patients with severe respiratory complications of COVID-19 [Internet]. Oxford: Nuffield Department of Population Health, University of Oxford; 2020. Available from: https://www. recoverytrial.net/news/low-cost-dexamethasonereduces-death-by-up-to-one-third-in-hospitalisedpatients-with-severe-respiratory-complicationsof-covid-19

38. Horby P, Landray M. No clinical benefit from use of hydroxychloroquine in hospitalised patients with COVID-19. RECOVERY Trial [Internet]. Oxford: Nuffield Department of Population Health, University of Oxford; 2020. Available from: https://www.recoverytrial.net/news/statementfrom-the-chief-investigators-of-the-randomisedevaluation-of-covid-19-therapy-recovery-trialon-hydroxychloroquine-5-june-2020-no-clinicalbenefit-from-use-of-hydroxychloroquine-inhospitalised-patients-with-co

39. Shen C, Wang Z, Zhao F, et al. Treatment of 
5 Critically Ill Patients with COVID-19 with Convalescent Plasma. JAMA. 2020;323(16):15821589. doi:10.1001/jama.2020.4783

40. World Health Organization. COVID-19: Situation update for the WHO African Region 15 April 2020 [Internet]. 2020. Available from: https://apps.who. int/iris/bitstream/handle/10665/331763/SITREP COVID-19 WHOAFRO 20200415-eng.pdf

41. Zahrotunnimah. Langkāh Taktis Pemerintah Daerah Dalam Pencegahan Penyebaran Virus Corona Covid-19 di Indonesia. SALAM J Sos dan Budaya Syar-i. 2020;7(3):247-60. doi: 10.15408/ sjsbs.v7i3.15103 